\title{
Editorial
}

\section{Arte, crítica social e tecnologia:}

\section{Interseções}

Editorial

\section{Art, social criticism and technology: \\ Intersections}

\section{Por Vera Follain de Figueiredo e Alexandre Carauta}

Os dez textos reunidos nesta edição revigoram o compromisso em conjugar comunicação, cultura, política, e irrigar reflexões com constantes diálogos entre os campos do saber. Com abordagens diversas, os textos reforçam a proposta da Alceu, incorporada ao Programa de PósGraduação (PPGCOM) do Departamento de Comunicação Social da PUC-Rio, de estimular e valorizar a pluralidade de visões e a densidade científica. De maneira não menos emblemática, a edição 42 consolida avanços editoriais e técnicos desenvolvidos ao longo (e apesar) deste ano difícil.

À tradição de duas décadas de vida, somam-se as estreias do padrão bilíngue dos artigos; da periodicidade quadrimestral (três edições anuais); das seções de entrevista, de tradução e de resenhas de livros; do novo ambiente digital, com mais funcionalidades e informações para leitores, autores, pareceristas, como a melhor visualização dos metadados (estatísticas). Novidades que revitalizam a excelência editorial e alinham totalmente a Alceu às diretrizes da Capes. Razões a mais para saborear esta edição.

O pluralismo da revista manifesta-se logo no texto de abertura: uma rica entrevista feita pelo professor titular (aposentado) da Universidade Estadual Paulista Marco Aurélio Nogueira, doutor 


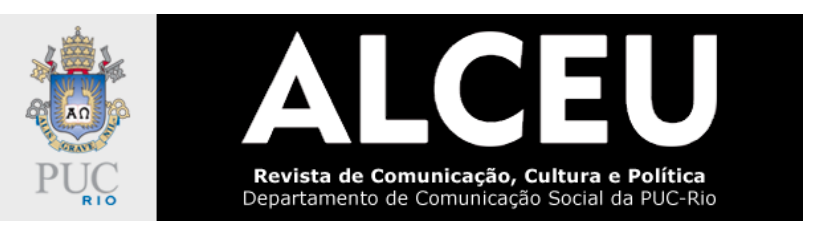

em Ciência Política (USP), com o cineasta, escritor e jornalista João Batista de Andrade, exsecretário de Cultura de São Paulo. O diretor do premiadíssimo O homem que virou suco, cujo lançamento está prestes a completar 40 anos, relembra passagens marcantes da vida e da obra dedicadas a capturar o universal da experiência humana.

Aos 81 anos, o intelectual nascido em Ituiutaba, Minas, reitera o entrelace entre a produção artística e a militância política. Com a habitual acuidade, ele alerta para um esgotamento cultural decorrente do "envelhecimento problemático de ideias filosóficas, das utopias, das chamadas ciências sociais e da política". A cultura, propõe João Batista de Andrade, precisa deixar de ser "lugar de privilégio" para consumar-se "lugar de libertação".

O texto seguinte, de Alexandre Silva Guerreiro, também transita na esquina entre as produções cinematográficas e a crítica social. Ao mergulhar no universo dardenneano - e em seus personagens às voltas com dilemas morais, num cenário de desumanização -, o artigo "Ética e encenação no cinema dos irmãos Dardenne: de $A$ promessa a $O$ jovem Ahmed" reflete sobre a influência dos ditames éticos nos filmes de Jean-Pierre e Luc Dardenne.

Na sequência, Márcia Gomes Marques e Gedy Brum Weis Alves evocam outro recorrente diálogo cinematográfico. Como indica o título, "Cinema e literatura: transposição intermidiática da história de um defunto autor", as pesquisadoras investigam, sob a perspectiva da intertextualidade e da hipertextualidade, a relação entre Memórias Póstumas de Brás Cubas, romance escrito por Machado de Assis em 1881, e o filme Memórias Póstumas, dirigido por André Klotzel em 2001. Elas apontam os elementos que se mantêm, os que se renovam e os que não se concretizam na obra adaptada.

A literatura também é o pano de fundo de "Livro-aplicativo: experiências mediadas por conflitos dados na materialidade". O artigo de Carina Ochi Flexor e Tatiana Guenaga Aneas vai ao encontro de um dos desdobramentos da reconfiguração midiática derivada das tecnologias digitais: a gamificação. Ao observarem processos de convergência, discutem as imbricações entre livroaplicativo e jogo inseridas na experiência do leitor-jogador. Elas observam tensões referentes a vivências fixadas no deslumbramento midiático.

O contexto cibercultural prolonga-se no texto seguinte: "Cultura digital: Sob reflexos (Eco) e fluxos (Flusser)". A partir de posicionamentos integrados e apocalípticos de Umberto Eco frente a 
inovações tecnológicas e do olhar crítico de Vilém Flusser acerca dos impactos da tecnologia na cultura, Olira Saraiva Rodrigues e Cleomar de Souza Rocha buscam desconstruir mitos e concepções deterministas em torno das mudanças comportamentais relacionadas à revolução digital.

As novas tecnologias da informação permeiam também o artigo seguinte. Em "Distribuição de jornais comunitários, interação e participação na comunicação contemporânea", Marcelo Ernandez Macedo desloca o foco das teorias comunicacionais - centrado na produção e na recepção de conteúdos informacionais - para a instância distributiva das informações. Com base na história da distribuição de periódicos impressos e na análise de entregas de jornais comunitários, o autor testa a hipótese de que a horizontalidade na comunicação depende menos das novas tecnologias da informação do que do modo como se valoriza a dialogia nos processos comunicativos.

Já Leonardo de Marchi e Gabriel Gutierrez constroem uma ponte entre os novos horizontes midiáticos e o mercado musical. Em "A mídia somos nós - as transformações da indústria fonográfica e o modelo de negócios dos Racionais MC's", eles avaliam o modelo de negócio do grupo nascido na periferia paulistana para compreender como o rap tem se articulado com a indústria fonográfica brasileira.

A convergência das mídias revela-se ainda o ponto de partida para a pesquisa de Noel dos Santos Carvalho e Gustavo Padovani, apresentada no artigo "O mundo multiplataforma Kondzilla: inovação no modelo de negócio audiovisual". Eles investigam o universo multiplataforma germinado pelo maior canal de música do YouTube brasileiro, com quase 60 milhões de seguidores. Um fenômeno que ganha corpo com a série ficcional Sintonia (Netflix, 2019) e o portal próprio de produção de conteúdo.

O som também conduz a triangulação orquestrada por Ney Costa Santos no ensaio "Tom Jobim e a música da Casa Assassinada". Ele analisa a trilha composta pelo maestro para o filme dirigido por Paulo Cesar Saraceni em 1971, adaptação do romance Crônica da casa assassinada, obra-prima de Lucio Cardoso. Com um lirismo bem brasileiro, avalia Ney, as variações melódicas de Jobim vão muito além da funcionalidade da música para o cinema. Constituem um "milagre, 


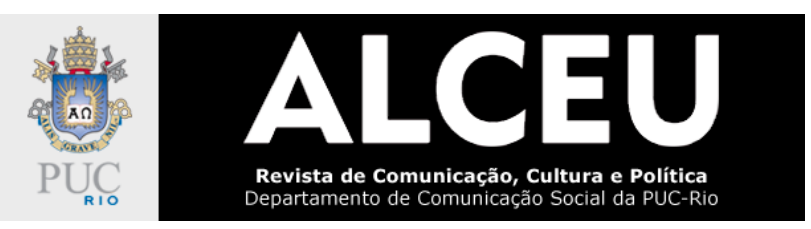

como o canteiro de violetas entre a fogueira das paixões que consomem a casa e os personagens e a delicadeza do perfume das flores no jardim abandonado".

Fecha esta edição a resenha de Luíza Alvim sobre o livro Rostos de Bergman: vida e morte em um plano. Organizado por Gustavo Chataignier, Tatiana Siciliano, Liliane Heynemann e Luiz Baez, reúne apreciações de diversos autores sobre sete filmes: Morangos silvestres, O sétimo selo, Gritos e sussurros, A hora do Lobo, Persona, Sonata de outono e Saraband. Luíza destaca o equilíbrio preciso da publicação: "entre textos de apresentação e textos analíticos, de vieses filosóficos, psicanalíticos e outros, a coletânea nos traz rostos imagéticos e sonoros da vida e da morte, duo fundamental na obra do diretor sueco".

Antes de nos despedirmos, agradecemos a vasta contribuição de Gustavo Chataignier, que abraça outros voos acadêmicos depois de dois anos à frente da revista, e saudamos a chegada de Vera Follain de Figueiredo. Parte da nova coeditora a sugestão do eixo temático da próxima edição (43), programada para abril de 2021: Distopia e narrativas contemporâneas: a difícil arte de imaginar o futuro. O dossiê abarca reflexões, em perspectivas diversas, sobre as implicações estéticas, éticas e políticas da representação apocalíptica do futuro, na produção cultural das duas últimas décadas.

Não obstante este eixo temático, do qual convidamos a comunidade científica a participar, a revista conserva a recepção de textos em fluxo contínuo.

Aproveitamos também para desejar um ano mais leve, fraterno, revigorante.

Boa leitura!

Vera Follain de Figueiredo

Editora da Revista Alceu Professora do Departamento de Comunicação da PUC-Rio

Doutora em Letras pela PUC-Rio ORCID: https://orcid.org/0000-0003-0142-6938

Alexandre Carauta

Editor da Revista Alceu Professor do Departamento de Comunicação da PUC-Rio

Doutor em Comunicação pela PUC-Rio ORCID: https://orcid.org/0000-0002-3607-8710 